\title{
Regulatory circuits involved with pH-regulated gene expression in Salmonella typhimurium
}

\author{
John W. Foster, ${ }^{1}$ Yong K. Park, ${ }^{2}$ lel Soo Bang, ${ }^{2}$ Kevin Karem, \\ Heather Betts, ${ }^{1}$ Holly K. Hall ${ }^{1}$ and Edward Shaw ${ }^{1}$
}

Author for correspondence: John W. Foster. Tel: +1205460 6323. Fax: +12054607931.

\begin{abstract}
Department of
Microbiology, College of

Medicine, University of

South Alabama, Mobile, AL 36688 , USA

2 Department of Biology, Korea University 1 Anam-

Dong, Seong buk-Ku, Seoul 136-701, Korea
\end{abstract}

\begin{abstract}
Salmonella typhimurium encounters a variety of acid conditions during both its natural and pathogenic existence. The ability of this organism to respond transcriptionally to low $\mathrm{pH}$ is an area of active interest but little knowledge. As part of an ongoing investigation of low-pH adaptation, $18 \mathrm{pH}-c o n t r o l l e d$ lacz operon fusions in Salmonella typhimurium have been identified (15 in this study) and categorized into at least 11 different loci. They include iroA (at $57 \mathrm{~min}$ ), aciA (99 min), aciB (90-93 min), aciD (ompC, $45 \mathrm{~min})$, aciJ, aciK (33-36 min), aniC (93 min), anil (33-36 min), hyd (59 min), cadA (54 min) and aniG (63 $\mathrm{min}$ ). All but two were induced by low pH. One of the exceptions, the iron-regulated iroA locus, was induced at high pH. The unusual aciA locus was induced by low pH under semiaerobic conditions but high pH under aerobic conditions. Most of the other aci genes were expressed best under anaerobic conditions. Many of these genes exhibited strict co-inducer requirements for small molecules to be expressed in minimal medium. These included iron for iroA, tyrosine for aniC, I and aciK, mannose for aniG, formate for hyd, lysine for cadA, and unknown components of complex medium for aciA, aciB and aciD. Six regulatory circuits were revealed involving at least five regulatory loci ( fur, oxrG, earAB, earC and ompR). As part of the adaptive response to low $\mathrm{pH}$, S. typhimurium will induce an acid protection system called the acid tolerance response (ATR). As has been shown for fur mutations, the oxrG regulatory mutation interfered with the normal induction of this system.
\end{abstract}

Keywords: Salmonella, $\mathrm{pH}$ regulation, gene expression, acid tolerance response, lysine decarboxylase, hydrogenase, fur, omp

\section{INTRODUCTION}

Salmonella typhimurium exhibits remarkable versatility in its molecular responses to diverse environmental stresses (Morgan et al., 1986; Aliabadi et al., 1986; Spector et al., $1986,1988)$. One perceived role for these systems is to overcome the impressive array of antimicrobial defences and physical barriers presented by the host (Finlay \& Falkow, 1989). The organism is known to sense various conditions in the host environment and respond by coordinately regulating sets of genes that will contribute to survival and, thus, infection (Mekalanos, 1992; Lee \& Falkow, 1990; Ernst et al., 1990; Valone et al., 1993; Buchmeier \& Heffron, 1990). Consequently, environmental stress management by Salmonella is an area of increasing interest.

Abbreviations: ATR, acid tolerance response; LDC, lysine decarboxylase.
Since $S$. typhimurium encounters a variety of life-threatening acid environments in both natural and pathogenic situations, we have been accumulating evidence for a $\mathrm{pH}$ response modulon. Part of this modulon includes a low$\mathrm{pH}$-inducible acid tolerance response (ATR) that will significantly increase acid resistance (Foster \& Hall, 1990). The ATR is a two-stage system that includes mild ( $\mathrm{pH} \mathrm{5.8)}$ and moderate $(\mathrm{pH} 4.3)$ acid adaptations called the preacid shock and postacid shock stages, respectively. An important manifestation of the preshock ATR stage is an inducible $\mathrm{pH}$ homeostasis mechanism that helps maintain intracellular $\mathrm{pH}$ above the lethal limit during strong acid stress (Foster \& Hall, 1991). Acid shock results in the increased synthesis of 43 proteins at least, some of which are required for survival in severe acid conditions (Foster, 1991). In addition to the ATR, there are a variety of amino acid decarboxylases that can serve to neutralize an acidic environment (Gale \& Epps, 1942). 
Table 1. Salmonella typhimurium strains used in this study

\begin{tabular}{|c|c|c|}
\hline Strain & Genotype & Source \\
\hline JF1023 & aniD1047:: MudA & Aliabadi et al. (1986) \\
\hline JF1141 & aniI1070::MudA & Aliabadi et al. (1986) \\
\hline JF1325 & aniC1052:: MudJ & Aliabadi et al. (1986) \\
\hline JF1509 & aniI1070:: MudA oxrG406:: Tn10 & Aliabadi et al. (1988) \\
\hline JF1593 & aniC1052::MudJ oxrG406:: $\operatorname{Tn} 10$ & Aliabadi et al. (1988) \\
\hline JF1842 & $o m p R:: \operatorname{Tn} 5$ & $\mathrm{LT} 2 \times \phi \mathrm{SF} 241$ \\
\hline JF1992 & $\operatorname{iro} A 1:: \mathrm{Mud} \mathrm{J}$ & This paper and Foster \& Hall (1992) \\
\hline JF2023 & fur 1 zf $f: \operatorname{Tn} 10\left(85 \%\right.$ linked to iro $\left.A^{+}\right)$ & $\mathrm{JF} 2021 \times \phi \mathrm{SF} 221$ \\
\hline $\mathrm{JF} 2147$ & iro $A 14:: \mathrm{Mu} d \mathrm{~J}$ & This paper \\
\hline JF2148 & iro $A 15:: \mathrm{MudJ}$ & This paper \\
\hline JF2149 & $\operatorname{aci} A 1:: \mathrm{Mu} d \mathrm{~J}$ & This paper \\
\hline JF2150 & $\operatorname{aci} A 2:: \mathrm{MudJ}$ & This paper \\
\hline JF2151 & $\operatorname{aci} A 3:: \mathrm{MudJ}$ & This paper \\
\hline JF2154 & iro $A 18: \mathrm{Mu} d \mathrm{~J}$ & This paper \\
\hline JF2161 & aci $A 3:: \mathrm{MudJ}$ earC1 & This paper \\
\hline JF2170 & earC1 $2 j j-5132:: \operatorname{Tn} 10\left(95 \%\right.$ linked to aci $\left.A^{+}\right)$ & JF2161 $\times \phi \operatorname{Tn} 10$ pool \\
\hline JF2236 & $a c i B:: \mathrm{MudJ}$ & This paper \\
\hline JF2237 & aciD9:: MudJ & This paper \\
\hline JF2238 & $\operatorname{cad} A 10:: \mathrm{Mu} d \mathrm{~J}$ & This paper \\
\hline JF2239 & 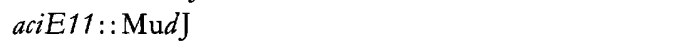 & This paper \\
\hline $\mathrm{JF} 2240$ & 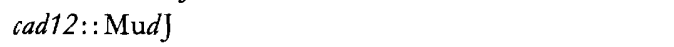 & This paper \\
\hline $\mathrm{JF} 2241$ & $\begin{array}{l}\text { aciB8:: MudJ earC1 } \approx j j-5132:: \operatorname{Tn} 10 \\
\left(95 \% \text { linked to aci } A^{+}\right)\end{array}$ & $\mathrm{JF} 2170 \times \phi \mathrm{JF} 2236$ \\
\hline JF2244 & aciB8:: $\mathrm{MudJ}$ earD1 & This paper \\
\hline JF2257 & aciD9::MudJ fur-1 \&f:: $\operatorname{Tn} 10$ & $\mathrm{JF} 2023 \times \phi \mathrm{JF} 2237$ \\
\hline JF2264 & aciD9:: MudJ earC1 ajj-5132:: $\operatorname{Tn} 10$ & $\mathrm{JF} 2170 \times \phi \mathrm{JF} 2237$ \\
\hline JF2265 & $\operatorname{cad} A 10:: \mathrm{MudJ}$ earC1 zjj-5132:: Tn10 & $\mathrm{JF} 2170 \phi \mathrm{JF} 2238$ \\
\hline JF2303 & $\operatorname{aciD9::\mathrm {Mu}d\mathrm {J}}$ & $\mathrm{LT} 2 \times \phi \mathrm{JF} 2237$ \\
\hline JF2449 & aci $A 3:: \mathrm{Mu} d \mathrm{~J}$ earC:: $\operatorname{Tn} 10(\mathrm{dTc})$ & $\mathrm{JF} 2161 \times \phi \operatorname{Tn} 10(\mathrm{dTc})$ pool \\
\hline JF2452 & $\begin{array}{l}\text { aciA3:: MudJ earC } C^{+} z e-5148:: \operatorname{Tn} 10(\mathrm{dTc}) \\
\left(50 \% \text { linked to } e \operatorname{arC} C^{+}\right)\end{array}$ & $\mathrm{JF} 2161 \times \phi \mathrm{Tn} 10(\mathrm{dTc})$ pool \\
\hline JF2495 & $\operatorname{cad} A 12:: \mathrm{MudJ}$ & This paper \\
\hline JF2509 & earD1 $z j c-5158:: \operatorname{Tn} 10\left(83 \%\right.$ linked to $\left.a c i B^{+}\right)$ & $\mathrm{JF} 2244 \times \phi \operatorname{Tn} 10(\mathrm{dTc})$ pool \\
\hline JF2563 & $\operatorname{aciD} 1(o m p C):: \operatorname{Tn} 10(\mathrm{dTc})$ & \\
\hline JF2575 & $\begin{array}{l}\text { aciD } 9(\text { ompC }):: \mathrm{MudJ} \text { earF1 } ₹ b f-5164:: \operatorname{Tn} 10(\mathrm{dTc}) \\
(80 \% \text {-linked to earF })\end{array}$ & $\mathrm{JF} 2303 \times \phi \mathrm{Tn} 10(\mathrm{dTc})$ pool \\
\hline JF2597 & aciJ2005:: MudJ & This paper \\
\hline JF2598 & $\operatorname{aciK2013::\mathrm {Mu}d\mathrm {J}}$ & This paper \\
\hline JF2628 & aciJ2005::MudJ fur -1 qfi:: Tn10 & $\mathrm{JF} 2023 \times \phi \mathrm{JF} 2597$ \\
\hline JF2629 & aciK2013:: MudJ fur-1 $z f i:: \operatorname{Tn} 10$ & $\mathrm{JF} 2023 \times \phi \mathrm{JF} 2598$ \\
\hline JF2643 & $\operatorname{cad} A 10:: \mathrm{MudJ} \operatorname{cad} C 3:: \operatorname{Tn} 10(\mathrm{dTc})$ & $\mathrm{JF} 2238 \times \phi \operatorname{Tn} 10(\mathrm{dTc})$ pool \\
\hline JF2644 & $\operatorname{cadC} 3:: \operatorname{Tn} 10(\mathrm{dTc})\left(\mathrm{LDC}^{-}\right)$ & This paper \\
\hline JF2645 & $\operatorname{cadC} 3:: \operatorname{Tn} 10(\mathrm{dTc}) / \mathrm{pPF} 106 \mathrm{cadC}^{+}($E. coli $)\left(\mathrm{LDC}^{+}\right)$ & This paper \\
\hline JF2651 & $\operatorname{aciD} 9(o m p C):: \mathrm{Mu} d \mathrm{~A}$ & $\mathrm{JF} 2237 \times \phi \mathrm{SF} 142$ \\
\hline JF2652 & $\operatorname{aciD} 9(o m p C):: \mathrm{Mu} d \mathrm{~A}$ ompR::Tn 5 & $\mathrm{JF} 2651 \times \phi \mathrm{SF} 241$ \\
\hline SF103 (SGSC184) & $\operatorname{trpR} 520 \operatorname{serB} 80$ & K. Sanderson \\
\hline SF142 (TT7692) & bisD9953:: MudA & J. Roth, Univ. of Utah, USA \\
\hline SF184 (TT5371) & 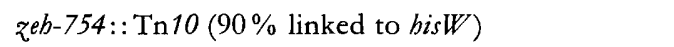 & J. Roth \\
\hline SF190 (DB9031) & zeb:: $\operatorname{Tn} 10(95 \%$ linked to $\operatorname{gyr} A)$ & $\begin{array}{l}\text { D. Botstein, Massachusetts Inst. } \\
\text { Technology, USA }\end{array}$ \\
\hline SF213 (TN858) & $\begin{array}{l}\text { leuBCD485 pepA1 pepB2 pepD3 ₹fd-801:: } \operatorname{Tn} 10 \\
(65 \% \text { linked to } p e p B)\end{array}$ & C. Miller, Univ. of Illinois, USA \\
\hline SF221 (KS177) & zfi:: $\operatorname{Tn} 10(2 \%$ linked to byd $)$ & K. Sanderson, Univ. of Calgary, Canada \\
\hline SF241 (CH511) & $o p p B C \Delta 250$ leu-1151:: $\operatorname{Tn} 10$ ompR::'Tn5 & C. Higgins, Univ. of Oxford, UK \\
\hline SF261 (TT10287) & bisD9953:: MudJ bis-9941::MudJ & J. Roth \\
\hline SF489 (SA2026) & metG419 & K. Sanderson \\
\hline
\end{tabular}


Determining how Salmonella typhimurium regulates its response to low $\mathrm{pH}$ is part of understanding how it survives potentially lethal low $\mathrm{pH}$ encounters. Toward that goal, we have initiated studies involving direct screening for $\mathrm{pH}$-regulated genes using the technique of Mud-lac operon fusion analysis (Hughes \& Roth, 1988). We previously identified two Salmonella genes, ani $G$ and byd, that require an acid environment for maximal induction (Aliabadi et al., 1988). These and several newly identified genes were examined in this current study. Identification and subsequent molecular dissection of these $\mathrm{pH}$-regulated genes will facilitate efforts designed to understand how cells sense and adapt to fluctuations in environmental $\mathrm{pH}$ and could reveal genes directly or indirectly involved in acid tolerance.

\section{METHODS}

Bacterial strains and culture conditions. The bacterial strains used throughout this study are all derivatives of Salmonella typbimurium LT2 and are listed in Table 1. Culture media included E medium (Vogel \& Bonner, 1956), Luria-Bertani (LB) medium (Davis et al., 1980) and NCE medium (Malloy \& Roth, 1983). LB was buffered to $100 \mathrm{mM}$ with either MES or MOPS as described by Slonczewski et al. (1987). Measurement of the adaptive ATR was detailed previously (Foster \& Hall, 1990). Briefly, cultures tested for the preacid shock stage were grown in $\mathrm{pH} 7.7$ minimal $\mathrm{E}$ glucose under semiaerobic conditions to $10^{8}$ cells $\mathrm{ml}^{-1}$, then adapted to $\mathrm{pH} 5 \cdot 8$ for one doubling. Unadapted cultures were grown directly to $2 \times$ $10^{8}$ cells $/ \mathrm{ml}$ at $\mathrm{pH} 7 \cdot 7$. Both cultures were then readjusted to pH 3.3 and incubated for $120 \mathrm{~min}$. Viable counts were taken at 0 and $120 \mathrm{~min}$. Cultures tested for the postacid shock stage of the ATR were grown at $\mathrm{pH} 7 \cdot 7$ to $2 \times 10^{8} \mathrm{cells} \mathrm{ml}^{-1}$, shifted to $\mathrm{pH} 4.3$ for $15 \mathrm{~min}$ then challenged at $\mathrm{pH} 3 \cdot 3$. The viable count values presented are the average of three independent experiments. The plasmid pABN203 containing the E. coli fur $r^{+}$locus under control of its native promoter was kindly provided by J. B. Neilands (Bagg \& Neilands, 1987). Iron depletion was accomplished through the addition of $100 \mu \mathrm{M}$ diethylene triamine pentacetic acid (DTPA), whilst iron replete conditions were established through supplementation with $60 \mu \mathrm{M} \mathrm{FeSO}_{4}$. Lysine decarboxylase (LDC) was assayed in Moeller decarboxylase medium (Difco).

Genetic and other procedures. Transductions were performed using P22 HT 105/1-int as described previously (Holley \& Foster, 1982; Aliabadi et al., 1988). The procedure to identify random $\mathrm{MudJ}$ fusions into $\mathrm{pH}$-regulated genes was as described by Slonczewski et al. (1987) using the technique of transitory ciscomplementation outlined by Hughes \& Roth (1988). Specific $\mathrm{pH}$-regulated insertions were identified by transducing LT2 to kanamycin resistance $\left(\mathrm{Km}^{\mathrm{r}}\right)$ on minimal medium plates containing a pool of amino acid and vitamin supplements excluding histidine. The $\mathrm{Km}^{\mathrm{r}}$ colonies were replicated to $\mathrm{E}$ medium (containing $\mathrm{X}$-gal and $\mathrm{Km}$ ) adjusted to $\mathrm{pH} 6.4$ and $8 \cdot 3$, and to buffered LB at pH 5.5 and 8.0. The construction of Tn 10 and lacZ-directed Hfr strains was as described by Chumley et al. (1978) and Spector et al. (1988). General mapping of Tn10 insertions using the Mud-P22 prophage system of Youderian $e t$ al. (1988), was performed as described by Benson \& Goldman (1992). Lysates from a specific Mud-P22 lysogen are enriched for the region of the chromosome starting at the hybrid phage insertion site and proceeding $3 \mathrm{~min}$ either clockwise or counterclockwise, depending on the phage orientation. Lysates pre- pared from each of the $48 \mathrm{Mud}$-P22 lysogens were spotted on to a lawn of Tet $^{r}$ cells plated on fusaric acid-containing medium (Malloy \& Nunn, 1981). Tetracycline-sensitive, fusaric acidresistant colonies arose in patches where donor chromosomal DNA spanned the region of the Tn10 insertion. Transformations were performed by electroporation (Tsai et al., 1989). Two-dimensional SDS-PAGE was performed as described by Spector et al. (1986). Cells were grown in minimal glucose medium ( $\mathrm{pH} 7 \cdot 0$ ) to a density of $4 \times 10^{8}$ cells $\mathrm{ml}^{-1}$ and labelled for $10 \mathrm{~min}$ with ${ }^{35} \mathrm{~S}$-Translabel from ICN Biomedicals. Assays of $\beta$-galactosidase production were performed as described by Miller (1972) and are expressed as $\mu \mathrm{mol}$ per min per $\mathrm{OD}_{600}$ unit. Values given are the average of three determinations and reflect a reproducibility of $\pm 10 \%$. Aerobiosis was achieved by growing $5 \mathrm{ml}$ of culture in a $50 \mathrm{ml}$ flask with shaking (240 r.p.m.). Anaerobiosis involved a standing culture with a paraffin oil overlay. A $3 \mathrm{ml}$ culture shaking at 240 r.p.m. in a $10 \times 100 \mathrm{~mm}$ test tube was used for semiaerobic conditions.

\section{RESULTS and DISCUSSION}

\section{Identification of pH-regulated genes}

An exhaustive search was made of a random $\mathrm{MudJ}$ insertion pool for $\mathrm{pH}$-regulated loci. As a result of this study, 15 strains were found to exhibit $\mathrm{pH}$-regulated $\beta$ galactosidase production (Table 2). Two other fusion strains, identified previously as $\mathrm{pH}$-regulated, were also studied (aniG and byd). Regulation was of two types, acidinducible and -repressible. Acid-regulated genes were designated aci unless something was known about their function or if they were identified previously by a different strategy. Genes designated iro and ani were regulated by iron and anaerobiosis, respectively.

Some of the fusions under study proved to be inducible in minimal medium (iro $A$ and aci $A$ ), whilst others required a component of complex medium for optimum induction (aciB, aciD, ani $C$, aniI, aciK, cad $A$ ). Efforts to identify these co-inducer requirements included adding combinations of amino acids and vitamins to minimal medium while testing induction. Lysine was required for $\operatorname{cad} A$ induction in minimal medium (Table 2). The $\operatorname{cad} A$ locus was subsequently shown to encode LDC as evidenced by the loss of LDC activity in the cad insertion mutants. This represents the first report, to our knowledge, identifying cad $A$ in Salmonella. Partial induction of aciD was achieved in minimal medium upon the addition of $3 \mathrm{mM}$ cysteine. The relevance of this is unclear but may be related to osmotic induction of this gene (see below). The aciK, aniC and aniI fusions were all induced in minimal medium by the addition of either L-tyrosine or L-phenylalanine. Induction of these three loci required low $\mathrm{pH}$, anaerobiosis and either one of these aromatic compounds. Salmonellae do not posses a tyrosine or phenylalanine decarboxylase, so the reason for this unusual regulation remains a mystery. They may represent an anaerobic equivalent of the aromatic amino acid transport systems which are also induced by tyrosine or phenylalanine (Heatwole \& Somerville, 1991; Sarsero et al., 1991). The aci $B$ locus also requires a co-inducer molecule but its identity remains unknown. It does not appear to be an amino acid based on the addition of pooled amino acids. 
Table 2. pH-regulated operon fusions

Growth was measured under semiaerobic conditions. $\beta$-Galactosidase activity values [expressed as $\mu \mathrm{mol}_{\mathrm{min}}^{-1}\left(\mathrm{OD}_{600} \mathrm{unit}^{-1}\right]_{\text {are }} \mathrm{means}^{-\mathrm{C}}$ of three determinations $\pm 10 \%$. Assays were according to Miller (1972). For all experiments, minimal E medium with glucose was used unless stated otherwise. ND, Not done.

\begin{tabular}{|c|c|c|c|c|c|c|}
\hline \multirow[t]{3}{*}{ Strain } & \multirow[t]{3}{*}{ Genotype } & \multirow[t]{3}{*}{ Addition } & \multicolumn{4}{|c|}{$\beta$-Galactosidase activity } \\
\hline & & & \multicolumn{2}{|c|}{ Minimal } & \multicolumn{2}{|c|}{ LB } \\
\hline & & & pH 5.8 & $\mathrm{pH} 7 \cdot 7$ & pH 5.5 & pH 8.0 \\
\hline JF1992 & iroA1::MudJ & & 25 & 430 & ND & ND \\
\hline $\int F 2147$ & iro $A 14:: \mathrm{Mu} d \mathrm{~J}$ & & 19 & 190 & ND & ND \\
\hline JF2148 & iro $A 15:: \mathrm{Mu} d \mathrm{~J}$ & & 20 & 233 & ND & ND \\
\hline JF2154 & $\operatorname{iro} A 18:: \mathrm{Mu} d \mathrm{~J}$ & & 21 & 390 & ND & ND \\
\hline JF2149 & $\operatorname{aci} A 1:: \mathrm{Mu} d \mathrm{~J}$ & & 200 & 16 & 510 & 170 \\
\hline $\int F 2150$ & $\operatorname{aci} A 2:: \mathrm{Mu} d \mathrm{~J}$ & & 210 & 16 & 690 & 243 \\
\hline JF2151 & $\operatorname{aci} A 3:: \mathrm{Mu} d \mathrm{~J}$ & & 110 & 9 & 663 & 155 \\
\hline JF2236 & aciB8: : MudJ & & 25 & 1 & 172 & 10 \\
\hline \multirow[t]{3}{*}{ JF2237 } & aciD9:: Mud $J$ & & $0 \cdot 0$ & $0 \cdot 0$ & 159 & 18 \\
\hline & & $3 \mathrm{mM}$ cysteine & 50 & 4 & ND & ND \\
\hline & & $300 \mathrm{mM} \mathrm{NaCl}$ & 21 & 3 & ND & ND \\
\hline \multirow[t]{2}{*}{ JF2238 } & $\operatorname{cad} A 10:: \mathrm{MudJ}$ & & $0 \cdot 0$ & $0 \cdot 0$ & 598 & 8 \\
\hline & & $10 \mathrm{mM}$ lysine & 1071 & 30 & ND & ND \\
\hline JF2495 & $\operatorname{cad} A 12:: \mathrm{MudJ}$ & & 0.5 & $0 \cdot 5$ & 540 & 6 \\
\hline JF2597* & aciJ2005:: MudJ & & 190 & 310 & 750 & 3 \\
\hline \multirow[t]{3}{*}{ JF2598* } & 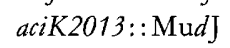 & & 10 & 2 & 275 & 25 \\
\hline & & $100 \mu \mathrm{M}$ tyrosine & 405 & $0 \cdot 0$ & ND & ND \\
\hline & & $600 \mu \mathrm{M}$ phenylanaline & 310 & $0 \cdot 0$ & ND & $\mathrm{ND}$ \\
\hline \multirow[t]{2}{*}{ JF1325* } & aniC::MudJ & & $0 \cdot 0$ & $0 \cdot 0$ & 311 & 41 \\
\hline & & Tyrosine & 473 & 2 & ND & ND \\
\hline \multirow[t]{2}{*}{ JF1141* } & aniI::MudJ & & 0.0 & $0 \cdot 0$ & 169 & 42 \\
\hline & & Tyrosine & 301 & 15 & ND & ND \\
\hline
\end{tabular}

* Expression only observed under anaerobic conditions.

The aciJ locus was unusual in that acid induction was clear in LB complex medium but expression was constitutive in minimal glucose (Table 2, JF2597). This could suggest that a corepressor molecule is required for $\mathrm{pH} 7.7$ repression although, again, the addition of amino acid pools to minimal media did not affect expression.

\section{Regulation by external vs internal pH}

There are three obvious parameters a cell could measure to trigger the induction of $\mathrm{pH}$-regulated genes. These are external $\mathrm{pH}\left(\mathrm{pH}_{\mathrm{o}}\right)$, internal $\mathrm{pH}\left(\mathrm{pH}_{\mathrm{i}}\right)$ or the difference between the two $(\Delta \mathrm{pH})$. Slonczewski et al. (1987) have devised a method to differentiate between internal and external inducing signals. The method involves the addition of a weak acid such as benzoate to culture media ( $\mathrm{pH} 7$ ). The protonated form of benzoate will cross the membrane and subsequently lower internal $\mathrm{pH}$. So if internal $\mathrm{pH}$ is the signal for aci induction, the addition of $20 \mathrm{mM}$ benzoate should lead to aci expression. The aci $A$, aci $B$, aciJ, aciK and $c a d A$ genes $\operatorname{did}$ not respond to this treatment. The aciD-lac $Z$ fusion was induced in LB $100 \mathrm{mM}$ MOPS (pH 7) containing $20 \mathrm{mM}$ benzoate (402 Miller units) as compared to $\mathrm{pH} 7$ containing no benzoate (27 Miller units) suggesting a role for $\mathrm{pH}_{\mathrm{i}}$ in the induction of this gene.

\section{Location and identity of pH-regulated loci}

Three of the acid-inducible lac $Z$ operon fusions noted above cotransduced to the same position on the $S$. typhimurium chromosome. Tn10 insertions that cotransduced with the insertion of JF2151 (aciA3:: Mud) were also linked to the insertions in JF2149 and JF2150. Tn10directed Hfr constructions using z jj-5132:: Tn 10 revealed the location of aci $A$ to be between 90 and $99 \mathrm{~min}$ (data not shown). Later use of the MudPQ set of mapping lysates also indicated a map position between 98 and $0 \mathrm{~min}$. Finally, a cotransductional linkage of $1 \%$ was demonstrated between zjj-5132::Tn10 (JF2170) and $\operatorname{ser} B$ (SF103), localizing aci $A$ to $99 \mathrm{~min}$. 
The aciB locus (JF2236) was mapped to between 90 and $93 \mathrm{~min}$ with the MudPQ system. Construction of lacdirected Hfrs using the aciB-lac operon fusion confirmed this and indicated a clockwise transcriptional orientation. We have discovered that aciB is linked $(15 \%)$ to the anaerobiosis-inducible aniD (JF2509 $\times$ JF1023) locus (Aliabadi et al., 1986).

Tn10 insertions near aciD were used to map this locus with the MudPQ system to between 40 and $50 \mathrm{~min}$. Cotransductional analysis with known markers in the area revealed that aciD is approximately $50 \%$ linked to zeb:: $\operatorname{Tn} 10(\mathrm{SF} 190 \times \mathrm{JF} 2444)$. This placed aciD at $45 \mathrm{~min}$ on the linkage map.

The fusions in JF2238, JF2240 and JF2495 all occurred within the cad $A$ locus as demonstrated by a deficiency in lysine decarboxylase. A $\operatorname{Tn} 10$ insertion near $\operatorname{cad} A$ was mapped to between 52 and $57 \mathrm{~min}$ using the $\mathrm{MudPQ}$ system. Cotransductional analysis subsequently placed cad at $54 \mathrm{~min}, 56 \%$ linked to purG:: $\operatorname{Tn} 10(\mathrm{SF} 256)$ and $3 \%$ to zfd-801:: Tn10 (SF213). This is very different from its position in Escherichia coli $(93 \mathrm{~min})$. Cloning and preliminary sequencing results (Park \& Foster, unpublished) indicate that, other than for map position, the $S$. typhimurium cadB $A$ operon is very similar to its counterpart in E. coli (Auger et al., 1989; Watson et al., 1992; Meng \& Bennett, 1992a, b).

The tyrosine-inducible ani $C$ and aniI loci were previously mapped to 93 and between 33 and $36 \mathrm{~min}$, respectively. Based on a similar tyrosine dependence for expression, $a c i K$ was tested for linkage to these two loci. Cotransduction results indicated aciK was $60 \%$ linked to aniI, (JF1141) placing it between 33 and $36 \mathrm{~min}$.

The alkaline induced iro $A$ locus was mapped to $57 \mathrm{~min}$ based upon cotransduction (85\%) with $z f i: \operatorname{Tn} 10$ (SF $221 \times \mathrm{JF} 1992$ ), This locus has an undefined role in iron transport. Its regulation by $\mathrm{pH}$ is due, at least in part, to the reduced solubility of $\mathrm{Fe}(\mathrm{OH})_{3}$ under alkaline $\mathrm{pH}$ since the addition of $60 \mu \mathrm{M} \mathrm{FeSO}_{4}$ to $\mathrm{pH} 7.7$ cultures fully repressed iro $A$ (JF1992, Table 2). All of the iro $A$ insertions have been mapped to the $57 \mathrm{~min}$ region and may represent insertions into the same gene. It should be noted that none of the other $\mathrm{pH}$-regulated genes identified were controlled by iron (data not shown).

\section{Identification of trans-acting regulators}

The earC regulator. Strains containing mutations in a trans-acting regulatory locus controlling aci $A$ were isolated by streaking bacteria containing aci $A-l a c Z$ fusions onto MacConkey lactose plates. These fusion strains have a $\mathrm{Lac}^{-}$phenotype toward the heavy streak area of the plate. However, red papillae representing spontaneous mutants arose within this area. All of the mutants selected were derepressed and deregulated with respect to $\mathrm{pH}$ regulated control of aciA (e.g. JF2161, Table 3). Five were subsequently tested for linkage between the regulatory mutation and the aci $A:: \mathrm{Mu} d \mathrm{~J}$ insertion. One regulatory mutation was linked; however, four were unlinked to the insertion and appear to represent mutations in one or more trans-acting regulatory loci. We have previously used the designation external acid regulator (ear) to refer to these genes and favour retaining this nomenclature until the specific function of the gene is determined (Foster \& Aliabadi, 1989). Consequently, we have designated the new trans-acting regulator as earC. Tn10 insertions were identified near the ear $C$ locus and used to map the gene to between 40 and $44 \mathrm{~min}$. Subsequent cotransduction with known markers indicated that the gene resides at $44 \mathrm{~min}$ and is $60 \%$ linked to met $G$ (JF2452 $\times$ SF489). The earC mutation caused deregulation of all three aci $A-$ lac $Z$ fusion strains. We also identified a Tn10dTc insertion into JF2161 (aci $A:: \mathrm{Mud}$ ear $(1)$ which eliminated aci $A-l a c Z$ expression resulting in a $\mathrm{Lac}^{-}$phenotype. The transposon also cotransduced with met $G(\mathrm{JF} 2449 \times \mathrm{SF} 489,90 \%)$ and appears to be an insertion into earC. Lack of aci $A$ expression in the earC::Tn10 background suggests earC is a positive regulator of aci $A$ (JF2449, Table 3).

The earF regulator. An aci $D-l a c Z$ culture mutagenized with mini $\operatorname{Tn} 10$ gave rise to a regulatory mutant that overexpressed aciD (JF2575). The regulatory mutation, ear $F 1$, was not caused by the $\operatorname{Tn} 10$ insertion itself but cotransduced with it ( $80 \%$ linkage). The effect of earF on aciD expression is shown in Table 3 . It is interesting that this mutation removed the co-inducer requirement for expression but did not affect $\mathrm{pH}$-regulated expression as shown in minimal media. This suggests the existence of a second, unknown, regulator that controls $\mathrm{pH}$ regulation of aciD. MudPQ mapping experiments placed earF between 72 and $79 \mathrm{~min}$. Subsequent cotransductional tests revealed that the $\mathrm{Tn} 10 \mathrm{dTc}$ insertion near earF cotransduced with $\operatorname{ompR}:: \operatorname{Tn} 5(\mathrm{JF} 2575 \times \mathrm{JF} 1842,80 \%)$. This raised the possibility that earF is in fact a mutation in ompR or envZ (see below).

The cadC regulator. Several investigators have demonstrated that $\operatorname{cad} A$ in $E$. coli occurs within an operon $(\operatorname{cadB} A)$. A gene upstream from $\operatorname{cadB} A$, called $\operatorname{cad} C$, produces a positive regulatory protein essential for $\operatorname{cad} B A$ expression. The $c a d C$ regulatory locus of $S$. typhimurium was discovered in our work by screening the various Tn10 insertions located near $\operatorname{cad} A$. Several of these were $\mathrm{LDC}^{-}$indicating a defect in $\operatorname{cad} A$ expression. A few were insertions into the $\operatorname{cadB} A$ operon and were not complemented by a cloned $c a d C$ locus from $E$. coli. However, three $\mathrm{LDC}^{-} \mathrm{Tn} 10$ insertions were complemented by this plasmid, indicating that the positive regulator of $\operatorname{cad} A$ expression was inactivated by the insertion (e.g. JF2643, Table 3; JF2645, Table 1).

The oxrG regulator. A mutation in a previously identified regulator $\operatorname{oxr} G:: \operatorname{Tn} 10)$ of aniC and aniI was tested for its effect on low-pH induction of these loci and of aciK. The data presented in Table 3 illustrate that $\operatorname{oxr} G^{+}$ is required for low $\mathrm{pH}$ expression of all three loci. Whilst a minor amount of low-pH induction remained, the level appears insignificant. The $\operatorname{oxr} G$ locus was mapped previously to $88 \mathrm{~min}$, near the oxidative stress regulator oxyR, but is distinct from oxyR (Aliabadi et al., 1988). We 
Table 3. Effect of regulatory mutations on $\mathrm{pH}$-regulated operon fusions

$\beta$-Galactosidase activity [expressed as $\mu \mathrm{mol} \mathrm{min}^{-1}\left(\mathrm{OD}_{600} \text { unit }\right)^{-1}$ ] was measured according to Miller (1972). All strains were grown throughout the experiment at the $\mathrm{pH}$ indicated under semiaerobic conditions. Minimal medium was unsupplemented except for experiments involving the ani $C$, aniI and ac $i K$ lac fusion strains in which tyrosine $(100 \mu \mathrm{M})$ was added. LB contained either $100 \mathrm{mM}$ MES (pH 5.5) or MOPS ( $\mathrm{pH} 8 \cdot 0)$ buffers.

\begin{tabular}{|c|c|c|c|c|c|}
\hline \multirow[t]{3}{*}{ Strain } & \multirow[t]{3}{*}{ Genotype } & \multicolumn{4}{|c|}{$\beta$-Galactosidase activity } \\
\hline & & \multicolumn{2}{|c|}{ Minimal glucose } & \multicolumn{2}{|c|}{ LB } \\
\hline & & pH 5.8 & $\mathrm{pH} 7 \cdot 7$ & pH 5.5 & pH 8.0 \\
\hline JF2151 & $\operatorname{aci} A:: \mathrm{Mu} d \mathrm{~J}$ & 88 & 6 & 600 & 210 \\
\hline JF2161 & aci $A:: \mathrm{MudJ}$ earC1 & 856 & 329 & 920 & 650 \\
\hline JF2449 & aci $A:: \mathrm{MudJ}$ earC::Tn10 (dTc) & 2 & 1 & 5 & 2 \\
\hline JF2236 & aciB8::MudJ & 11 & 9 & 118 & 8 \\
\hline JF2244 & aciB8: : MudJ earD1 & 150 & 1.0 & 94 & 125 \\
\hline JF2241 & aciB8:: MudJ earC & & & 110 & 0 \\
\hline JF2238 & $\operatorname{cad} A:: \mathrm{MudJ}$ & & & 440 & 4 \\
\hline JF2265 & $\operatorname{cad} A:: \mathrm{Mu} d \mathrm{~J}$ earC & & & 382 & 4 \\
\hline JF2643 & $\operatorname{cad} A:: \mathrm{Mud} \operatorname{cad} C:: \operatorname{Tn} 10$ & & & 11 & 13 \\
\hline JF2237 & aciD9:: $\mathrm{Mu} d \mathrm{~J}$ & 0 & 0 & 190 & 25 \\
\hline JF2264 & $\operatorname{aciD9}:: \mathrm{Mu} d \mathrm{~J}$ earC & & & 211 & 31 \\
\hline JF2575 & aciD9:: $\mathrm{Mu} d \mathrm{~J}$ earF1(ompR) & 260 & 15 & 638 & 239 \\
\hline JF2651 & $\operatorname{aciD9::MudJ}$ & 22 & 7 & 190 & 17 \\
\hline JF2652 & aciD9::MudJ ompR:: Tn5 & 83 & $1 \cdot 5$ & 0 & 9 \\
\hline JF1325 & aniC1052::MudJ & 532 & 4 & & \\
\hline JF1593 & aniC1052::MudJ oxrG::Tn10 & 19 & 4 & & \\
\hline JF1141 & anil1070::MudJ & 321 & 11 & & \\
\hline JF1509 & aniI1070::MudJ oxrG:: $\operatorname{Tn} 10$ & 17 & 1 & & \\
\hline JF2598 & aciK2013::MudJ & 415 & 1 & & \\
\hline JF2647 & aciK2013::MudJ oxrG:: $\operatorname{Tn} 10$ & 7 & 1 & & \\
\hline
\end{tabular}

originally categorized $\operatorname{oxr} G$ as an oxygen sensitive regulator. However, with its observed effect on $\mathrm{pH}$-regulated gene expression, it is now unclear whether it is involved with $\mathrm{O}_{2}$ and/or $\mathrm{pH}$ sensing. Nevertheless, it is essential for the expression of this $\mathrm{pH}$-controlled regulon.

\section{The effect of osmolarity and anaerobiosis on aci expression}

It is recognized that many environmentally responsive genes respond to more than one environmental condition. We sought to test the aci fusions for similar multiple controls by screening them for regulation by osmolarity and anaerobiosis. For studies of osmotic control, LB adjusted to a $\mathrm{pH}$ of 7 was formulated to contain 0,200 or $400 \mathrm{mM} \mathrm{NaCl}$. A pH of 7 does not normally trigger induction of most aci loci. Cells were grown to exponential phase in these media and $\beta$-galactosidase assayed. The results (Table 4 ) reveal that three loci were clearly affected by osmolarity, cad $A$, aciB and aciD. The magnitude of control by osmotic conditions was less than by low $\mathrm{pH}$ but there was a definite effect upon induction. The aciD locus was induced by high osmolarity, whilst the other two genes were induced by low osmolarity. The map positions of aciD and its regulator earF suggest they are ompC, encoding an outer-membrane porin, and $a m p \mathrm{R}$ or env $Z$, the regulators of $\operatorname{omp} C$, respectively (Forst et al., 1990). Subsequent two-dimensional PAGE gels showed OmpC is missing in JF2337, indicating aciD is ompC (data not shown) $E$. coli om $p C$ is induced by low $\mathrm{pH}$ and high salt which is consistent with our results (Hyde \& Portalier, 1987). Hyde \& Portalier (1987) also found that envZ mutations within E. coli eliminate most of the $\mathrm{pH}$ control for $o m p F$ and $o m p C$. Whilst this also proved true for $e a r F$ aciD double mutants in $\mathrm{LB}$, the earF mutation now allowed significant $\mathrm{pH}$ control (15-20-fold) in minimal medium (JF2575, Table 3). Introduction of a known ompR::Tn5 insertion into an aciD(ompC):: MudA derivative strain also exposed significant $\mathrm{pH}$ regulation in minimal medium. But instead of enhancing expression in $\mathrm{LB}$, as was the case for earF mutations, ompR::Tn5 prevented expression of aciD (ompC) (JF2652, Table 3). The results suggest that environmental sensing by the 
Table 4. The effect of oxygen and osmolarity on aci-lacz expression

$\beta$-Galactosidase activity [expressed as $\mu \mathrm{mol} \mathrm{min}^{-1}\left(\mathrm{OD}_{600} \text { unit }\right)^{-1}$ ] was measured according to Miller (1972). LB medium was used throughout unless otherwise indicated.

\begin{tabular}{|c|c|c|c|c|c|c|c|}
\hline \multirow[t]{3}{*}{ Strain } & \multirow[t]{3}{*}{ Genotype } & \multirow[t]{3}{*}{$\mathrm{pH}$} & \multicolumn{5}{|c|}{$\beta$-Galactosidase activity } \\
\hline & & & \multirow[t]{2}{*}{$+\mathbf{O}_{2}$} & \multirow[t]{2}{*}{$-\mathrm{O}_{2}$} & \multicolumn{3}{|c|}{$\mathrm{NaCl}$ concn $(\mathrm{mM}) *$} \\
\hline & & & & & 0 & 200 & 400 \\
\hline \multirow[t]{3}{*}{ JF2236 } & aciB8:: MudJ & $5 \cdot 5$ & 38 & 29 & & & \\
\hline & & 7 & 24 & 30 & 34 & 6 & 0 \\
\hline & & $8 \cdot 0$ & 6 & 12 & & & \\
\hline \multirow[t]{3}{*}{ JF2237 } & aciD9:: MudJ & $5 \cdot 5$ & 165 & 117 & & & \\
\hline & & 7 & 8 & 30 & 5 & 15 & 42 \\
\hline & & $8 \cdot 0$ & 13 & 10 & & & \\
\hline \multirow[t]{3}{*}{$J F 2238$} & $\operatorname{cad} A 10:: \mathrm{MudJ}$ & $5 \cdot 5$ & 443 & 3352 & & & \\
\hline & & 7 & 37 & 600 & 251 & 11 & 6 \\
\hline & & $8 \cdot 0$ & 15 & 0 & & & \\
\hline \multirow[t]{3}{*}{ JF2495 } & $\operatorname{cad} A 12:: \mathrm{Mu} d \mathrm{~J}$ & $5 \cdot 5$ & 1018 & 6940 & & & \\
\hline & & 7 & 9 & 225 & 200 & 2 & 0 \\
\hline & & $8 \cdot 0$ & 9 & 6 & & & \\
\hline \multirow[t]{3}{*}{ JF2150 } & acd.42::MudJ & $5 \cdot 5$ & $10(90 t)$ & $1062(92 \dagger)$ & & & \\
\hline & & 7 & 263 & 1491 & 177 & 195 & 205 \\
\hline & & $8 \cdot 0$ & $385(42 \dagger)$ & $1202(430 \dagger)$ & & & \\
\hline \multirow[t]{3}{*}{$J F 2597$} & aciJ2005:: MudJ & $5 \cdot 5$ & 4 & 1261 & & & \\
\hline & & 7 & 2 & 430 & 8 & 10 & 12 \\
\hline & & $8 \cdot 0$ & 4 & 8 & & & \\
\hline \multirow[t]{3}{*}{ JF2598 } & aciK2013::MudJ & $5 \cdot 5$ & 2 & 669 & & & \\
\hline & & 7 & 1 & 76 & 21 & 15 & 9 \\
\hline & & $8 \cdot 0$ & 2 & 7 & & & \\
\hline
\end{tabular}

* Cultures were grown under partial aerobic conditions. Base LB contained no salt in this series.

† Results in minimal media.

EnvZ/OmpR two-component system is even more complicated that the current models suggest. The finding that mutations within EnvZ/OmpR allow pH-regulated expression of aciD $(\operatorname{mp} p C)$-lac in minimal medium indicate the existence of an additional $\mathrm{pH}$-dependent regulatory locus.

We also examined the effect of anaerobiosis on the induction of this set of low-pH-regulated genes (Table 4). Of the 10 acid-inducible genes identified, seven were also induced under anaerobic conditions. These were aci $A$, $\operatorname{cad} A$, aciJ, aciK, ani $C$, aniI and byd. The cad $A$ locus was very sensitive to oxygen levels and was clearly anaerobically induced, as was found for the analogous locus in E. coli (Auger et al., 1989). As with byd and cad $A$, both the aciJ and aciK loci were strictly induced by low $\mathrm{pH}$ and anaerobiosis. This pattern was maintained in minimal media. The reason why these genes are optimally expressed anaerobically is probably linked to the fermentative production of acid. Certainly, the byd locus will facilitate the dissimilation of formic acid, directly preventing a decrease in $\mathrm{pH}_{\mathrm{o}}$. LDC, in contrast, will produce an alkaline product that will titrate fermentative acid endproducts.

Interestingly, aci $A$ was subject to a very complex set of environmental controls when grown in LB. Anaerobically, aci $A$ was fully induced and exhibited no $\mathrm{pH}$ control. Under semiaerobic conditions it was acid-induced (threefold, Table 3), but under aerobic conditions it was acid-repressed (30-fold, Table 4). Conversely, under acid conditions it was anaerobically induced 100 -fold, whilst in alkaline conditions only fourfold anaerobic induction was observed. In addition, there must be an enhancing coinducer molecule for aciA since expression was much greater in LB than in minimal media. Expression in minimal medium was also greatest under anaerobic, alkaline conditions, but, as seen in Table 2 , it became acidinduced under semiaerobic conditions (12-fold). The reason(s) for the intricate controls placed on aci $A$ are unknown. It appears that anaerobiosis represents the primary control for this gene. However, a demand for the aci $A$ product also occurs aerobically if the cells are subjected to high $\mathrm{pH}$. The effects seen under semiaerobic 


\section{Table 5. Effect of fur mutations on $\mathrm{pH}$ regulated operon fusions}

$\beta$-Galactosidase activity was measured according to Miller (1972). All strains were grown throughout the experiment at the $\mathrm{pH}$ indicated. LB contained either $100 \mathrm{mM}$ MES ( $\mathrm{pH} 5 \cdot 5$ ) or MOPS ( $\mathrm{pH} 8 \cdot 0$ ) buffers.

\begin{tabular}{|c|c|c|c|c|c|}
\hline \multirow[t]{3}{*}{ Strain } & \multirow[t]{3}{*}{ Genotype } & \multicolumn{4}{|c|}{$\beta$-Galactosidase activity } \\
\hline & & \multicolumn{2}{|c|}{ Minimal glucose } & \multicolumn{2}{|c|}{ LB } \\
\hline & & pH 5.8 & pH 7.7 & pH 5.5 & pH 8.0 \\
\hline JF1992 & iroA:: MudJ & 7 & 569 & & \\
\hline JF2021 & $\operatorname{iro} A:: \mathrm{Mu} d \mathrm{~J} f u r$ & 306 & 411 & & \\
\hline JF2151 & $\operatorname{aci} A:: \mathrm{Mu} d \mathrm{~J}$ & 130 & 20 & 245 & 61 \\
\hline JF2212 & aci $A:: \mathrm{Mu} d \mathrm{~J}$ fur & 40 & 15 & 272 & 2 \\
\hline JF2236 & $a c i B 8:: \mathrm{MudJ}$ & 11 & 9 & 118 & 8 \\
\hline JF2242 & aciB8::Mud] fur & & & 124 & 6 \\
\hline JF2238 & $\operatorname{cad} A:: \mathrm{Mu} d \mathrm{~J}$ & & & 440 & 4 \\
\hline JF2266 & $\operatorname{cad} A:: \mathrm{Mu} d \mathrm{~J}$ fur & & & 403 & 4 \\
\hline JF2237 & aciD-9::MudJ & & & 179 & 13 \\
\hline $\mathrm{JF} 2257$ & aciD-9::MudJ fur & & & 223 & 54 \\
\hline JF2597 & aciJ: : MudJ & & & $645^{*}$ & $2 *$ \\
\hline JF2628 & aciJ:: $\mathrm{MudJ}$ fur & & & $730^{*}$ & $0^{*}$ \\
\hline JF2598 & $a c i K:: \mathrm{Mu} d \mathrm{~J}$ & $383 \dagger$ & $5 \dagger$ & & \\
\hline JF2629 & $a c i K:: \mathrm{Mu} d \mathrm{~J}$ fur & $222 t$ & $0 \dagger$ & & \\
\hline
\end{tabular}

* Grown anaerobically.

$\dagger$ Growth anaerobically with $100 \mu \mathrm{M}$ tyrosine for JF2598 and JF2629.

conditions must reflect the competition between oxygen and $\mathrm{pH}$ controls.

\section{The effect of fur mutations on pH-regulated gene expression}

The fur (ferric uptake regulator) locus encodes a major iron-regulatory protein in both E. coli and S. typhimurium, although its role in cellular physiology is thought to extend beyond iron metabolism (Hantke, 1981, 1987; Foster \& Hall, 1992). We have reported previously that fur mutations in Salmonella severely compromise the ability of this organism to mount an effective ATR (Foster \& Hall, 1992). One explanation for why fur mutations may prevent adaptive acid tolerance is that the Fur regulator might be required for optimal expression of specific acidinducible genes, some of which may be involved with acid tolerance. Consequently, the various aci-lac strains identified in our laboratory were used to construct aci-lac fur derivatives and aci-lac $Z$ expression subsequently measured under acid and alkaline conditions. The results presented in Tables 5 and 6 reveal that fur $^{+}$is clearly required for regulated expression of iro $A$ and maximum expression of byd in minimal medium. Of the remaining aci fusions, only aci $A$ appeared to be influenced by fur. However, the effect was not dramatic and thus not pursued further. The role of fur in iron-regulated control of iro $A$ was shown previously (Foster \& Hall, 1992). The data in Table 5 illustrates a similar role for fur in the $\mathrm{pH}$ control of iro $A$. It is unclear at this point whether iro $A$ responds directly to both $\mathrm{Fe}^{3+}$ and $\mathrm{pH}$ or whether the decreased solubility of $\mathrm{Fe}(\mathrm{OH})_{3}$ at alkaline $\mathrm{pH}$ is sufficient to explain the $\mathrm{pH}$ effect. However, if that were the case one might expect all iron-regulated genes should be subject to significant $\mathrm{pH}$ control. Evidence to the contrary was found in that at least one iron-regulated locus in Salmonella displays very little control by $\mathrm{pH}$, indicating $\mathrm{pH}$ has a varied effect on iron-regulated genes (N. Buchmeier \& J. Foster, personal communication).

Maximal induction of the byd locus, which encodes a component of hydrogenase, has been shown to require an acid pH, anaerobiosis and formate (Pecher et al., 1983; Schlensog \& Böck, 1990). The hydrogenase system may aid in the maintenance of $\mathrm{pH}_{\mathrm{i}}$ through the evolution of $\mathrm{H}_{2}$ gas and the dissimilation of formic acid. Schlensog \& Böck (1990) proposed that $\mathrm{pH}$ control of the E. coli hydrogenase loci was due to an effect on uptake of the inducer, formate. However, we found in S. typhimurium that mutations in fur severely limited induction of byd (JF2235 and 2392, Table 6) both in terms of anaerobiosis and $\mathrm{pH}$. Thus, the byd locus requires the fur product for complete induction. Regulation of other oxygen- and $\mathrm{pH}$ regulated (aniC, ani $G, a c i D, c a d A$ ) genes remained undisturbed by the fur mutations, indicating that Fur specifically affects the expression of some, but not all, 
Table 6. The effect of fur mutations on hyd-lacz expression

$\beta$-Galactosidase activity [expressed as $\mu \mathrm{mol} \min ^{-1}\left(\mathrm{OD}_{600}\right.$ unit) ${ }^{-1}$ ] was measured according to Miller (1972). ND, Not determined.

\begin{tabular}{|c|c|c|c|c|c|c|c|c|}
\hline \multirow[t]{3}{*}{ Strain } & \multirow[t]{3}{*}{ Genotype } & \multirow[t]{3}{*}{ Addition } & \multicolumn{6}{|c|}{$\beta$-Galactosidase activity } \\
\hline & & & \multicolumn{2}{|c|}{$\mathbf{L B}-\mathrm{O}_{2}$} & \multicolumn{2}{|c|}{ Minimal pH 5.8 } & \multicolumn{2}{|c|}{ Minimal $-\mathrm{O}_{2}$} \\
\hline & & & pH 5.5 & pH 8.0 & $-\mathbf{O}_{2}$ & $+\mathbf{O}_{2}$ & pH 5.8 & $\mathrm{pH} 7 \cdot 8$ \\
\hline JF927 & byd::MudA & & 371 & $1 \cdot 3$ & 510 & 2 & 600 & 70 \\
\hline \multirow{2}{*}{ JF1065 } & byd:: MudA oxr $A(f n r)$ & & 102 & $1 \cdot 0$ & 183 & 2 & 176 & 16 \\
\hline & & $30 \mathrm{mM}$ formate & 350 & $10 \cdot 0$ & 521 & 5 & 550 & 110 \\
\hline JF2235 & byd:: MudA fur-1 & & 11 & 0 & 11 & 2 & 0 & 0 \\
\hline JF2292 & byd::MudA fur-1/pABN203fur ${ }^{+}$ & & 310 & 12 & ND & ND & 375 & 66 \\
\hline \multirow[t]{2}{*}{ JF1534 } & byd::MudJ & & & & & & 790 & 42 \\
\hline & & $120 \mu \mathrm{M} \mathrm{FeSO}_{4}$ & & & & & 750 & 150 \\
\hline \multirow[t]{2}{*}{ JF2392 } & byd::MudJ fur-2 & & & & & & 0 & 0 \\
\hline & & $30 \mathrm{mM}$ formate & & & & & 0 & 0 \\
\hline JF900 & aniC::MudA & & & & $220^{*}$ & $20^{*}$ & & \\
\hline JF2234 & aniC: : MudA fur & & & & $195 *$ & $5^{*}$ & & \\
\hline $\mathrm{JF} 1295$ & $\operatorname{ani} G:: \mathrm{Mu} d \mathrm{~J}$ & & 470 & 30 & & & & \\
\hline JF2233 & aniG: : MudJ fur-1 & & 500 & 45 & & & & \\
\hline JF1537 & aniG:: MudJ ear $A$ & & 1900 & 2510 & & & & \\
\hline
\end{tabular}

* aniC was done in LB + glucose.

acid-inducible genes (Tables 5 and 6). It should be pointed out that there was no obvious difference between the growth rates of fur $^{+}$or fur derivatives. Extended growth of the fur mutants still did not result in any byd-lac $Z$ expression which argues against fur mutants simply delaying expression. Introduction of $\mathrm{pABN} 203$, which carries the fur ${ }^{+}$locus of $E$. coli, completely restored regulated expression of the byd-lac fusion (Table 6, JF2292).

The results indicate that either directly or indirectly, Fur influences the expression of at least two $\mathrm{pH}$-regulated genes, iro $A$ and byd. One question we wanted to address was whether or not a variation in iron availability due to a $\mathrm{pH}$ effect on $\mathrm{Fe}(\mathrm{OH})_{3}$ solubility could be solely responsible for the $\mathrm{pH}$-regulated expression of these loci. As noted above, the case for $\operatorname{iro} A$ was unclear since we could not unequivocally separate $\mathrm{pH}$ from iron regulation. The byd locus, however, was more amenable to study in this regard. As shown in Table 6 (JF1534), the shift from $\mathrm{pH} 7.8$ to 5.8 induced byd 19-fold. Adding 60-240 $\mu \mathrm{M}$ iron to $\mathrm{pH} 7 \cdot 8$ media did result in a modest threefold induction when compared to $\mathrm{pH} 7 \cdot 8$ without excess iron but did not fully compensate for the $\mathrm{pH}$ effect as was seen with iro $A$. This suggests two important features for byd expression. Firstly, holo-Fur $\left(\mathrm{Fur}+\mathrm{Fe}^{2+}\right)$ is required for the induction of this locus and secondly, iron availability alone does not account for $\mathrm{pH}$-regulated gene expression.

The oxygen-regulatory fnr product is known to indirectly affect byd expression by diminishing the production of formate, a requirement for byd induction (Birkman et al., 1987; Sawers \& Böck, 1989; Aliabadi et al., 1986). The possibility that fur mutants might prevent byd expression in a similar manner was eliminated since the addition of excess formate to byd:: MudJ fur mutants did not increase byd expression beyond backgrounds levels whereas formate addition did reverse the effect of an $f n r$ mutation (Table 6). The fact that holo-Fur, normally considered a repressor, may act as a positive regulator of gene expression confirms earlier studies involving twodimensional SDS-PAGE analysis from Salmonella (Foster \& Hall, 1992) and lac $Z$ fusion studies from E. coli involving the oxygen-regulated genes $d m s A$ (Cotter $e t$ al., 1992) and $\operatorname{sod} A$ (Beaumont \& Hassan, 1992). It is not clear whether Fur acts directly as an activator or indirectly in the form of a regulatory cascade. The question of how Fur may affect some $\mathrm{pH}$-regulated genes in an apparently ironindependent manner is enigmatic. We have shown through two-dimensional polypeptide analysis that fur mutations affect the production of several ATR gene products (Foster \& Hall, 1992). Some of these gene products are not produced in response to iron limitation under the conditions tested. Consequently, the mechanism by which Fur affects the expression of these loci is intriguing.

\section{OxrG is involved in acid tolerance}

As noted above, one reason for conducting these studies was to identify genes associated with acid tolerance in $S$. typhimurium. Two of the genes tested, fur and $\operatorname{axr} G$ have clear effects upon the ATR. The fur locus and its involvement in acid tolerance have been presented previously (Foster, 1991; Foster \& Hall, 1992). Acid tolerance of the $\operatorname{exr} G:: \operatorname{Tn} 10$ mutant is shown in Table 7. 
Table 7. The effect of oxrG on the ATR

Values are the means of three experiments. Reproducibility was within $30 \%$ of the viable counts given (e.g. $1 \cdot 5 \times 10^{8} \pm 0 \cdot 04 \times 10^{8}$ cells $\mathrm{ml}^{-1}$ ).

\begin{tabular}{|c|c|c|c|c|c|c|}
\hline \multirow[t]{3}{*}{ Strain } & \multirow[t]{3}{*}{ Genotype } & \multirow{3}{*}{$\begin{array}{c}\text { Time } \\
\text { (h) }\end{array}$} & \multicolumn{4}{|c|}{ No. of cells surviving } \\
\hline & & & \multicolumn{2}{|c|}{ Pre-acid shock* } & \multicolumn{2}{|c|}{ Post-acid shock $\dagger$} \\
\hline & & & Unadapted & Adapted & Unadapted & Adapted \\
\hline \multirow[t]{3}{*}{$\mathrm{LT} 2$} & $\operatorname{oxr} G^{+}$ & 0 & $1.5 \times 10^{8}$ & $2 \times 10^{8}$ & $2.3 \times 10^{8}$ & $1.9 \times 10^{8}$ \\
\hline & & 1 & $6 \times 10^{7}$ & $2 \times 10^{8}$ & $2 \cdot 3 \times 10^{7}$ & $1.5 \times 10^{8}$ \\
\hline & & 2 & $3.7 \times 10^{6}$ & $2 \times 10^{8}$ & $2 \cdot 11 \times 10^{4}$ & $9.5 \times 10^{7}$ \\
\hline \multirow[t]{3}{*}{ JF1436 } & $\operatorname{oxr} G:: \operatorname{Tn} 10$ & 0 & $1.7 \times 10^{8}$ & $1 \times 10^{8}$ & $1 \times 10^{8}$ & $1.3 \times 10^{8}$ \\
\hline & & 1 & $4.5 \times 10^{5}$ & $<2 \times 10^{2}$ & $8 \times 10^{5}$ & $9 \cdot 1 \times 10^{7}$ \\
\hline & & 2 & $5 \cdot 1 \times 10^{4}$ & $<2 \times 10^{2}$ & $1 \times 10^{4}$ & $3.9 \times 10^{7}$ \\
\hline
\end{tabular}

* Pre-acid shock adaptation. Unadapted cells $\mathrm{pH} 7 \cdot 7$, adapted cells $\mathrm{pH} 5 \cdot 8$ for 1 generation. Survival shown at 0,1 and $2 \mathrm{~h}$ after adjusting $\mathrm{pH}$ to $3 \cdot 3$.

† Post-acid shock adaptation. Unadapted cells at $\mathrm{pH} 7 \cdot 7$, adapted cells at $\mathrm{pH} 4 \cdot 3$ for $15 \mathrm{~min}$. Survival shown at 0,1 and $2 \mathrm{~h}$ after adjusting $\mathrm{pH}$ to $3 \cdot 3$.

There are two stages involved in the low-pH-inducible ATR system. They include the pre-acid shock phase induced at $\mathrm{pH} 5.8$ and a post-acid shock phase induced at levels below $\mathrm{pH} 4 \cdot 5$. A main function of the pre-acid shock stage is to improve $\mathrm{pH}$ homeostasis (Foster \& Hall, 1991) and allow synthesis of post-acid shock proteins (ASPs) to occur below pH 4.0. Among the ASPs are key acid protection proteins essential for acid tolerance (Foster, 1993). As shown in Table 7, the oxrG mutant was defective in the early pre-acid shock phase of ATR in which cells were adapted to $\mathrm{pH} 5 \cdot 8$ prior to challenge at $\mathrm{pH} 3 \cdot 3$. These cells exhibited a $5 \mathrm{log}$ decrease in cell number, even when adapted, as compared to a less than $1 \log$ decrease for adapted LT2. However, this mutant displayed a normal ATR if the post-acid shock stage was engaged at $\mathrm{pH} 4.3$ prior to $\mathrm{pH} 3 \cdot 3$ challenge. In this case, viability of adapted ( $\mathrm{pH} 4 \cdot 3$ ) oxrG cells decreased by a factor less than 1 log after acid challenge ( $\mathrm{pH} 3 \cdot 3)$.

In conclusion, the growing interest in $\mathrm{pH}$-regulated gene expression in E. coli and S. typhimurium has resulted in the identification of many genetic loci demonstrably regulated by $\mathrm{pH}$. They include aniG (Aliabadi et al., 1988), adi, cad A (Auger et al., 1989), byd (Aliabadi et al., 1988; Pecher et al., 1983), lysU (Hirshfield et al., 1984), ompF, ompC, lamB (Hyde \& Portalier, 1987; Foster \& Hall, 1990) and $l d b$ (Mat-Jan et al., 1989). Cytochrome $o$ and $d$ oxidases are recent additions to this list of $\mathrm{pH}$-regulated genes. Cotter et al. (1990) have shown that in E. coli, cyo is repressed by acid, whilst $c y d$, in a $\Delta f n r$ background, is distinctly acidinducible. We can now add aci $A, B, D, J$ and $K$, as well as ani $C$ and $I$ to this growing list.

We have also discovered several regulatory loci, in addition to fur and ear $A B$ (Foster \& Aliabadi, 1989), that appear to mediate control of specific subsets of $\mathrm{pH}$ regulated genes. These include the $\operatorname{ear} C$ and $\operatorname{oxr} G$ loci which regulate aci $A$ and the ani $C, I$, aciK regulon, respectively. In all, our studies have revealed six $\mathrm{pH}-$ sensitive control circuits in $S$. typhimurium. The sensory transduction mechanism(s) which must sense a change in external $\mathrm{pH}$ and subsequently transmit a signal to the transcriptional apparatus is not understood. However, it is interesting to note that most, if not all, of the target $\mathrm{pH}$ regulated genes require a second component for induction; mannose for $a n i G$, lysine for $\operatorname{cad} A$, formate for $b y d$, tyrosine for aniCI and aciK, and still unknown components of complex media for $a c i B, D$, and even aci $A$. The significance of this trend is not readily apparent but could suggest the existence of surface sensory proteins with coinducer binding sites that are conformationally triggered at low or high $\mathrm{pH}$. Studies are now underway to examine these molecular aspects of $\mathrm{pH}$-controlled gene expression in Salmonella.

\section{ACKNOWLEDGEMENTS}

The many lively discussions with Z. Aliabadi, H. Winkler and $M$. Spector are appreciated. The authors would also like to thank N. Nixon and P. Couling for their careful preparation of this manuscript. This work was supported by National Institutes of Health award GM 48017 and National Science Foundation grant DCB-89-04039 (J.W.F.), and Korean Ministry of Education GERG and YONAM Foundation grants (Y.K.P.).

\section{REFERENCES}

Aliabadi, Z., Warren, F., Mya, S. \& Foster, J. W. (1986). Oxygenregulated stimulons of Salmonella typhimurium identified by Mud(Aplac) operon fusions. J Bacteriol 165, 780-786.

Aliabadi, Z., Park, Y. K., Slonczewski, J. L. \& Foster, J. W. (1988). Novel regulatory loci controlling oxygen and $\mathrm{pH}$-regulated gene expression in Salmonella typhimurium. J Bacteriol 170, 842-851.

Auger, E. A., Redding, K. E., Plumb, T., Childs, L. C., Meng, S.-Y. \& Bennett, G. N. (1989). Construction of lac fusions to the inducible arginine- and lysine decarboxylase genes of Eschericbia coli K-12. Mol Microbiol 3, 609-620. 
Bagg, A. \& Neilands, J. B. (1987). Ferric uptake regulation protein acts as a repressor, employing iron(II) as a cofactor to bind the operator of an iron transport operon in Escherichia coli. Biochemistry 26, $5471-5477$.

Benson, N. R. \& Goldman, B. S. (1992). Rapid mapping in Salmonella typhimurium with Mud-P22 prophages. J Bacteriol 174, 1673-1681.

Beaumont, M. D. \& Hassan, H. M. (1992). Characterization of trans-acting regulatory elements affecting the expression of $\mathrm{Mn}$ superoxide dismutase $(\operatorname{sod} A)$ in Escherichia coli. Curr Microbiol 25, 135-141.

Birkman, A., Zinoni, F., Sawers, G. \& Böck, A. (1987). Factors affecting transcriptional regulation of the formate-hydrogen-lyase pathway of E. coli. Arch Microbiol 148, 44-51.

Buchmeier, N. A. \& Heffron, F. (1990). Induction of Salmonella stress proteins upon infection of macrophages. Science 248, 730-732.

Chumley, F. G., Menzel, R. \& Roth, J. R. (1978). Hfr-formation directed by $\operatorname{Tn} 10$. Genetics $\mathbf{9 1}, 639-655$.

Cotter, P. A., Darie, S. \& Gunsalas, R. P. (1992). The effect of iron limitation of the aerobic and anaerobic electron transport pathway genes in Escherichia coli. FEMS Microbiol Lett 100, 227-232.

Davis, R. W., Botstein, D. \& Roth, J. R. (1980). A Manual for Genetic Engineering. Advanced Bacterial Genetics. Cold Spring Harbor, NY: Cold Spring Harbor Laboratory.

Ernst, R. K., Dombroski, D. M. \& Merrick, J. (1990). Anaerobiosis, type 1 fimbriae and growth phase are factors that affect invasion of HEp-2 cells by Salmonella typhimurium. Infect Immun 58, 2014-2016.

Finlay, B. B. \& Falkow, S. (1989). Salmonella as an intracellular parasite. Mol Microbio/ 3, 1833-1841.

Forst, S., Douglas, J., Rampersaud, A. \& Inouye, M. (1990). In vivo phosphorylation of $O \mathrm{mpR}$, the transcriptional activator of ompF and $a m p C$ genes in Escherichia coli. J Bacteriol 172, 3473-3477.

Foster, J. W. (1991). Salmonella acid shock proteins are required for the acid tolerance response. J Bacteriol 173, 6896-6902.

Foster, J.W. (1993). The acid tolerance response of Salmonella typhimurium involves transient synthesis of key acid shock proteins. J Bacteriol 175, 1981- 1987.

Foster, J. \& Aliabadi, Z. (1989). $\mathrm{pH}$-regulated gene expression in Salmonella: genetic analysis of aniG and cloning of the ear $A$ regulator. Mol Microbiol 3, 1605-1615.

Foster, J. W. \& Hall, H. K. (1990). Adaptive acidification tolerance response of Salmonella typhimurium. J Bacteriol 172, 771-778.

Foster, J. W. \& Hall, H. K. (1991). Inducible $\mathrm{pH}$ homeostasis and the acid tolerance response of Salmonella typhimurium. J Bacteriol 173, 5129-5135.

Foster, J. W. \& Hall, H. K. (1992). Effect of Salmonella typhimurium ferric uptake regulator ( fur ) mutations on iron and $\mathrm{pH}$-regulated protein synthesis. $J$ Bacteriol 174, 4317-4323.

Gale, E. F. \& Epps, H. M. R. (1942). The effect of the $\mathrm{pH}$ of the medium during growth on the enzymic activities of bacteria ( $E$. coli and $M$. (ysodiekticus) and the biological significance of the changes produced. Biochem J 36, 600-619.

Hantke, K. (1981). Regulation of ferric iron transport in Escherichia coli K12: isolation of a constitutive mutant. Mol \& Gen Genet 182, 288-292.

Hantke, K. (1987). Selection procedure for deregulated iron transport mutants ( $f u r)$ in Escherichia coli K12: fur not only affects iron metabolism. Mol \& Gen Genet 210, 135-139.

Heatwole, V. M. \& Somerville, R. L. (1991). The tryptophanspecific permease gene, $m$ tr, is differentially regulated by the tryptophan and tyrosine repressor in Escherichia coli K12.J Bacteriol 173, 3601-3604.
Hirshfield, I. N., Tenreiro, R., Vanbogelen, R. A. \& Neidhardt, F. C. (1984). Escherichia coli $\mathrm{K}-12$ lysyl-tRNA synthetase mutant with a novel reversion pattern. $J$ Bacteriol 158, 615-620.

Holley, E. A. \& Foster, J. W. (1982). Bacteriophage P22 as a vector for Mu mutagenesis in Salmonella typhimurium: isolation of nad-lac and pnc-lac gene fusions. J Bacteriol 152, 959-962.

Hughes, K. \& Roth, J. (1988). Transitory cis-complementation: a general method for providing transposase to defective transposons. Genetics 119, 9-12.

Hyde, M. \& Portalier, R. (1987). Regulation of major outer membrane porin proteins of E. coli K-12 by pH. Mol \& Gen Genet 208, 511-517.

Lee, C. A. \& Falkow, S. (1990). The ability of Salmonella to enter mammalian cells is affected by bacterial growth state. Proc Natl Acad Sci US A 87, 4304-4308.

Malloy, S. R. \& Nunn, W. D. (1981). Selection for loss of tetracycline resistance by Escherichia coli. J Bacterio/ 145, 1110-1112.

Malloy, S. R. \& Roth, J. R. (1983). Regulation of proline utilization in Salmonella typhimurium: characterization of put::Mud(Aplac) operon fusions. J Bacteriol 154, 561-568.

Mat-Jan, F., Alam, K. Y. \& Clark, D. P. (1989). Mutants of Escherichia coli deficient in the fermentative lactate dehydrogenase. $J$ Bacteriol 171, 342-348.

Mekalanos, J. J. (1992). Environmental signals controlling expression of virulence determinants in bacteria. J Bacteriol 174, 1-7.

Meng, S.-Y. \& Bennett, G. (1992a). Nucleotide sequence of the Escherichia coli cad operon: a system for neutralization of low extracellular pH. J Bacteriol 174, 2659-2669.

Meng, S.-Y. \& Bennett, G. (1992b). Regulation of the Escherichia coli cad operon: location of a site required for acid induction. J Bacteriol 174, 2670-2678.

Miller, J. H. (1972). Experiments in Molecular Genetics. Cold Spring Harbor, NY: Cold Spring Harbor Laboratory.

Morgan, R. W., Christman, M. F., Jacobson, F. S., Sturz, G. \& Ames, B. N. (1986). Hydrogen peroxide-inducible proteins in Salmonella typhimurium overlap with heat shock and other stress proteins. Proc Natl Acad Sci US A 83, 8059-8063.

Pecher, A., Zinoni, F., Jatisatienr, C., Wirth, R., Hennecke, H. \& Böck, A. (1983). On the redox control of synthesis of anaerobically induced enzymes in enterobacteriaceae. Arcb Microbiol 136, 131-136.

Sarsero, J. P., Wookey, P. J. \& Rottard, A. J. (1991). Regulation of expression of the Escherichia coli K-12 mtr gene by $\mathrm{T}_{\mathrm{yrR}} \mathrm{R}$ protein and Trp repressor. J Bacteriol 173, 4133-4143.

Sawers, G. \& Böck, A. (1989). Novel transcriptional control of pyruvate formate-lyase gene: upstream regulatory sequences and multiple promoters regulate anaerobic expression. J Bacteriol 171, 2485-2498.

Schlensog, V. \& Böck, A. (1990). Identification and sequence analysis of the gene encoding the transcriptional activator of the formate hydrogenlyase system of Escherichia coli. Mol Microbiol 4, 1319-1326.

Slonczewski, J. L., Gonzalez, T. N., Bartholomew, M. \& Holt, N. J. (1987). Mud-directed lac $Z$ fusions regulated by acid $\mathrm{pH}$ in Escberichia coli. J Bacteriol 169, 3001-3006.

Spector, M. P., Aliabadi, Z., Gonzalez, T. \& Foster, J. W. (1986). Global control in Salmonella typhimurium: two-dimensional electrophoretic analysis of starvation-, anaerobiosis- and heat shockinducible proteins. J Bacteriol 168, 420-424.

Spector, M. P., Park, Y. K., Tirgari, S., Gonzalez, T. \& Foster, J. W. (1988). Identification and characterization of starvation-regulated 
genetic loci in Salmonella typbimurium by using $\mathrm{Mud}$-directed lac $\mathrm{Z}$ operon fusions. J Bacteriol 170, 345-351.

Tsai, S.P., Hartin, R. J. \& Ryu, J. (1989). Transformation in restriction Salmonella typhimurium LT2. J Gen Microbiol 135, 2561-2567.

Valone, S. E., Chikami, G. K. \& Miller, V. L. (1993). Stress induction of the virulence proteins ( $\mathrm{Spv} A,-\mathrm{B}$ and $-\mathrm{C}$ ) from native plasmid pSDL2 of Salmonella dublin. Infect Immun 61, 705-713.

Vogel, H. J. \& Bonner, D. M. (1956). Acetylornithinase of Eschericbia coli: partial purification and some properties. J Biol Chem 218, 97-106.
Watson, N., DunYak, D. S., Rosey, E. L., Slonczewski, J. L. \& Olsen, E. R. (1992). Identification of elements involved in transcriptional regulation of the Escherichia coli cad operon by external pH. J Bacteriol 174, 530-540.

Youderian, P., Sugino, P., Brewer, K. L., Higgins, N. P. \& Elliot, T. (1988). Packaging specific segments of the Salmonella chromosome with locked-in Mud-P22 prophages. Genetics 118, 581-592.

Received 14 June 1993; revised 10 August 1993; accepted 26 August 1993. 